\title{
Front Matter: Volume 6459
}

, "Front Matter: Volume 6459," Proc. SPIE 6459, Laser-based Micro- and Nanopackaging and Assembly, 645901 (23 March 2007); doi:

$10.1117 / 12.729338$

EDIE Event: Lasers and Applications in Science and Engineering, 2007, San Jose, SPIE. California, United States 


\title{
PROCEEDINGS OF SPIE
}

\section{Laser-based Micro- and Nanopackaging and Assembly}

\author{
Wilhelm Pfleging \\ Yongfeng Lu \\ Kunihiko Washio \\ Friedrich G. Bachmann \\ Willem Hoving \\ Editors
}

22-24 January 2007

San Jose, California, USA

Sponsored and Published by

SPIE-The International Society for Optical Engineering

Volume 6459

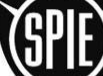

The International Society for Optical Engineering

Proceedings of SPIE-The International Society for Optical Engineering, 9780819465726, v. 6459

SPIE is an international technical society dedicated to advancing engineering and scientific applications of optical, photonic, imaging, electronic, and optoelectronic technologies. 
The papers included in this volume were part of the technical conference cited on the cover and title page. Papers were selected and subject to review by the editors and conference program committee. Some conference presentations may not be available for publication. The papers published in these proceedings reflect the work and thoughts of the authors and are published herein as submitted. The publisher is not responsible for the validity of the information or for any outcomes resulting from reliance thereon.

Please use the following format to cite material from this book:

Author(s), "Title of Paper," in Laser-based Micro- and Nanopackaging and Assembly, edited by Wilhelm Pfleging, Yongfeng Lu, Kunihiko Washio, Friedrich G. Bachmann, Willem Hoving, Proceedings of SPIE Vol. 6459 (SPIE, Bellingham, WA, 2007) Article CID Number.

ISSN 0277-786X

ISBN 9780819465726

Published by

SPIE-The International Society for Optical Engineering

P.O. Box 10, Bellingham, Washington 98227-0010 USA

Telephone 1 360/676-3290 (Pacific Time) · Fax 1 360/647-1445

http://www.spie.org

Copyright (@ 2007, The Society of Photo-Optical Instrumentation Engineers

Copying of material in this book for internal or personal use, or for the internal or personal use of specific clients, beyond the fair use provisions granted by the U.S. Copyright Law is authorized by SPIE subject to payment of copying fees. The Transactional Reporting Service base fee for this volume is $\$ 18.00$ per article (or portion thereof), which should be paid directly to the Copyright Clearance Center (CCC), 222 Rosewood Drive, Danvers, MA 01923. Payment may also be made electronically through CCC Online at http://www.copyright.com. Other copying for republication, resale, advertising or promotion, or any form of systematic or multiple reproduction of any material in this book is prohibited except with permission in writing from the publisher. The CCC fee code is 0277$786 \times / 07 / \$ 18.00$.

Printed in the United States of America. 


\section{Contents}

vii Conference Committee

\section{SESSION 1 WELDING AND BONDING}

645902 Requirements and potentialities of packaging for bioreactors with LTCC and polymer (Invited Paper) [6459-01]

U. Klotzbach, V. Franke, F. Sonntag, L. Morgenthal, E. Beyer, Fraunhofer Institute Material and Beam Technology (Germany)

645903 Laser welding of micro plastic parts [6459-02]

E. Haberstroh, W.-M. Hoffmann, RWTH Aachen Univ. (Germany)

645904 Hybrid micro-optical system integration by laserbeam soldering [6459-03]

E. Beckert, R. Eberhardt, H. Banse, A. Tünnermann, Fraunhofer IOF (Germany);

F. Buchmann, Askion GmbH (Germany); M. Fettke, PacTech GmbH (Germany)

645905 Laser-based rework in electronics production [6459-04]

F. Albert, I. Mys, M. Schmidt, Bayerisches Laserzentrum GmbH (Germany)

\section{SESSION 2 MICROFLUIDICS}

645906 Combined laser texturing and molecular vapor deposition for wetting angle control (Invited Paper) [6459-05]

M. F. Jensen, K. Vestentoft, K. B. Haugshøj, L. H. Christensen, Danish Technological Institute (Denmark)

645907 Laser-assisted modification of polymers for microfluidic, micro-optics, and cell culture applications [6459-06]

W. Pfleging, R. Adamietz, Forschungszentrum Karlsruhe GmbH (Germany); H. J. Brückner, Univ. of Applied Sciences (Germany); M. Bruns, A. Welle, Forschungszentrum Karlsruhe GmbH (Germany)

Pagination: Proceedings of SPIE follow an e-First publication model, with papers published first online and then in print and on CD-ROM. Papers are published as they are submitted and meet publication criteria. A unique, consistent, permanent citation identifier (CID) number is assigned to each article at the time of the first publication. Utilization of CIDs allows articles to be fully citable as soon they are published online, and connects the same identifier to all online, print, and electronic versions of the publication.

SPIE uses a six-digit CID article numbering system in which:

- The first four digits correspond to the SPIE volume number.

- The last two digits indicate publication order within the volume using a Base 36 numbering system employing both numerals and letters. These two-number sets start with 00, 01, 02, 03, 04, 05, 06, 07, 08, 09, OA, OB ... 0Z, followed by 10-1Z, 20-2Z, etc.

The CID number appears on each page of the manuscript. The complete citation is used on the first page, and an abbreviated version on subsequent pages. 
645908 Rapid prototyping of microfluidic components by laser beam processing (Invited Paper) [6459-07]

M. Wehner, P. Jacobs, R. Poprawe, Fraunhofer Institute for Lasertechnology (Germany)

645909 Laser micromachining of optical biochips [6459-08]

A. D. Goater, UK Laser Micromachining Ctr. (United Kingdom) and Univ. of Wales, Bangor (United Kingdom); J. P. H. Burt, Univ. of Wales, Bangor (United Kingdom) and UK Laser Micromachining Ctr. (United Kingdom); D. J. Morris, A. Menachery, Univ. of Wales, Bangor (United Kingdom); N. H. Rizvi, UK Laser Micromachining Ctr. (United Kingdom);

D. R. Matthews, H. D. Summers, Cardiff Univ. (United Kingdom)

SESSION 3 OPTICS AND PHOTONICS

64590A Development of micro-mirrors in optical-electric printed wiring boards using excimer laser (Invited Paper) [6459-09]

T. Matsushima, K. Tanaka, T. Nakashiba, Y. Yagyu, M. Kubo, Matsushita Electric Works, Ltd. (Japan)

64590B Femtosecond laser microfabrication of subwavelength structures in photonics [6459-10] V. Mezentsev, J. S. Petrovic, M. Dubov, I. Bennion, Aston Univ. (United Kingdom); J. Dreher, Ruhr-Univ. Bochum (Germany); H. Schmitz, Aston Univ. (United Kingdom) and Ruhr-Univ. Bochum (Germany); R. Graver, Ruhr-Univ. Bochum (Germany)

SESSION 4 MICRO- AND NANOMACHINING I

64590F Deep-UV laser-based nano-patterning with holographic techniques [6459-14]

D. Sawaki, J. Amako, Seiko Epson Corp. (Japan)

$64590 \mathrm{G}$ Machining hole arrays in polyimide using a UV solid state laser and predetermined temporal pulse patterns [6459-15]

C. Mullan, D. Ilie, G. M. O'Connor, S. Favre, T. J. Glynn, National Univ. of Ireland/Galway (Ireland)

$64590 \mathrm{H}$ Processing benefits of high repetition rate and high average power $355 \mathrm{~nm}$ laser for micromachining of microelectronics packaging materials [6459-16]

R. S. Patel, J. Bovatsek, Newport Corp. (USA)

645901 New high-repetition-rate high-energy $308 \mathrm{~nm}$ excimer laser for material processing [6459-17]

L. Herbst, I. Klaft, K. Schmidt, I. Bragin, H.-S. Albrecht, Coherent GmbH (Germany)

64590J Potentials of fiber laser technology in microfabrication [6459-18]

V. Franke, U. Klotzbach, M. Panzner, R. Püschel, Fraunhofer Institute Material and Beam

Technology (Germany)

SESSION 5 MICRO- AND NANOMACHINING II

64590K High-precision small geometry laser trimming for emerging microelectronics devices

(Invited Paper) [6459-19]

B. Gu, GSI Group (USA)

iv 
$64590 \mathrm{M}$ The promise of solar energy: applications and opportunities for laser processing in the manufacturing of solar cells [6459-21]

C. M. Dunsky, Coherent, Inc. (USA)

$64590 \mathrm{~N}$ Mechanisms of femtosecond laser nanomachining of dielectric surfaces [6459-22]

S. I. Kudryashov, P.N. Lebedev Physical Institute (Russia); A. Joglekar, Univ. of North Carolina at Chapel Hill (USA); G. Mourou, ENSTA-Ecole Polytechnique (France); A. A. Ionin,

V. D. Zvorykin, P.N. Lebedev Physical Institute (Russia); A. J. Hunt, Univ. of Michigan (USA)

645900 Micro-machining of the ceramics: Can lasers match the performance of diamond saws? [6459-23]

D. Patterson, G. P. Singh, Hitachi Global Storage Technologies (USA)

64590P The Laser MicroJet (LMJ): a multi-solution technology for high quality micro-machining [6459-24]

T. A. Mai, B. Richerzhagen, Synova SA (Switzerland); P. C. Snowdon, D. Wood,

P. G. Maropoulos, Durham Univ. (United Kingdom)

\section{SESSION 6 MICRO- AND NANOMATERIALS}

64590 Laser-induced formation of photocatalytic $\mathrm{TiO}_{2}$ micronetworks on a UV-absorbing glass surface (Invited Paper) [6459-25]

A. Narazaki, Y. Kawaguchi, H. Niino, National Institute of Advanced Industrial Science and Technology (Japan); M. Shojiya, H. Koyo, K. Tsunetomo, Nippon Sheet Glass Co., Ltd. (Japan)

64590R Laser modification of ceramic surfaces with micro- and nanoparticles [6459-26] M. Rohde, Forschungszentrum Karlsruhe GmbH (Germany)

64590 Fabrication of back-gated SWNT field-effect transistor by laser chemical vapor deposition [6459-27]

J. Shi, Y. S. Zhou, Y. F. LU, Y. S. Lin, S. H. Liou, Univ. of Nebraska/Lincoln (USA)

64590T Enhancement of Raman scattering using silica microparticles [6459-28]

K. J. Yi, Y. F. LU, H. Wang, Z. Y. Yang, Univ. of Nebraska/Lincoln (USA)

$64590 \mathrm{U}$ Precision laser bending of thin precious metal alloys [6459-29]

R. C. Campbell, B. R. Campbell, T. M. Lehecka, The Pennsylvania State Univ. (USA);

J. A. Palmer, G. A. Knorovsky, Sandia National Labs. (USA)

\section{SESSION 7 THIN FILMS}

$64590 \mathrm{~V}$ Laser-assisted maskless fabrication of flexible electronics (Invited Paper) [6459-30] C. P. Grigoropoulos, S. H. Ko, H. Pan, Univ. of California/Berkeley (USA); J. Chung, Korea Univ. (South Korea); D. Poulikakos, ETH Zurich (Switzerland)

64590W Laser deposition and structuring of laser active planar waveguides of Er:ZBLAN, Nd:YAG, and Nd:GGG for integrated waveguide lasers [6459-31]

J. Gottmann, L. Moiseev, D. Wortmann, I. Vasilief, L. Starovoytova, D. Ganser, R. Wagner, RWTH Aachen (Germany) 
64590X Deposition of functionalized nanoparticles in multilayer thin-film structures by resonant infrared laser ablation [6459-32]

M. R. Papantonakis, U.S. Naval Research Lab. (USA); E. Herz, Cornell Univ. (USA);

D. L. Simonson, U.S. Naval Research Lab. (USA); U. B. Wiesner, Cornell Univ. (USA);

R. F. Haglund, Jr., Vanderbilt Univ. (USA)

$64590 \mathrm{Y} \mathrm{CO}_{2}$ laser-assisted local deposition of diamond films by combustion-flame method [6459-33]

H. Ling, Y. X. Han, Y. F. Lu, Univ. of Nebraska/Lincoln (USA)

$64590 Z$ Synthesis of diamond on WC-Co substrates using a KrF excimer laser in combination with a combustion flame [6459-34]

Y. X. Han, H. Ling, Y. F. LU, Univ. of Nebraska/Lincoln (USA)

\section{POSTER SESSION}

645910 CNT-BLU fabrication by laser-induced local material transfer [6459-35]

C.-W. Cheng, S.-C. Liao, H.-T. Chen, ITRI South (Taiwan); J.-R. Ho, J.-W. J. Cheng, H.-Y. Liao, National Chung Cheng Univ. (Taiwan); L.-E. Chou, ITRI (Taiwan)

645911 Microstructure devices generation by selective laser melting [6459-36]

J. J. Brandner, E. Hansjosten, E. Anurjew, W. Pfleging, K. Schubert, Forschungszentrum Karlsruhe GmbH (Germany)

Author Index 


\title{
Conference Committee
}

\author{
Symposium Chairs
}

Friedrich G. Bachmann, Rofin-Sinar Laser GmbH (Germany)

Henry Helvajian, The Aerospace Corporation (USA)

Program Track Chairs

Henry Helvajian, The Aerospace Corporation (USA)

James S. Horwitz, U.S. Department of Energy (USA)

Conference Chairs

Wilhelm Pfleging, Forschungszentrum Karlsruhe GmbH (Germany)

Yongfeng Lu, University of Nebraska/Lincoln (USA)

Kunihiko Washio, Paradigm Laser Research Ltd (Japan)

Conference Cochairs

Friedrich G. Bachmann, Rofin-Sinar Laser GmbH (Germany)

Willem Hoving, Philips Applied Technologies (Netherlands)

Program Committee

Dieter Bäuerle, Johannes Kepler Universität Linz (Austria)

Shaochen Chen, The University of Texas at Austin (USA)

Richard F. Haglund, Jr., Vanderbilt University (USA)

Amako Jun, Seiko Epson Corporation (Japan)

Thomas Klotzbücher, Institut für Mikrotechnik Mainz GmbH (Germany)

Sergey I. Kudryashov, Arkansas State University (USA)

Xinbing Liu, Panasonic Technologies Company (USA)

Tuan Anh Mai, Synova SA (Switzerland)

Vladimir Mezentsev, Aston University (United Kingdom)

Andreas Ostendorf, Laser Zentrum Hannover e.V. (Germany)

Marius Przybylski, ATL Lasertechnik GmbH (Germany)

Vladimir V. Semak, The Pennsylvania State University (USA)

Gurinder P. Singh, Hitachi Global Storage Technologies (USA)

Koji Sugioka, The Institute of Physical and Chemical Research (Japan)

Vadim P. Veiko, Saint-Petersburg State University (Russia)

\section{Session Chairs}

1 Welding and Bonding

Friedrich G. Bachmann, Rofin-Sinar Laser GmbH (Germany) 
2 Microfluidics

Udo Klotzbach, Fraunhofer-Institut für Werkstoff- und Strahltechnik (Germany)

3 Optics and Photonics

Willem Hoving, Philips Applied Technologies (Netherlands)

$4 \quad$ Micro- and Nanomachining I

Wilhelm Pfleging, Forschungszentrum Karlsruhe GmbH (Germany)

5 Micro- and Nanomachining II

Kunihiko Washio, Paradigm Laser Research Ltd (Japan)

6 Micro- and Nanomaterials

Yongfeng Lu, University of Nebraska/Lincoln (USA)

$7 \quad$ Thin Films

Bo Gu, GSI Group Inc. (USA) 